IRA-International Journal of Education \& Multidisciplinary Studies

ISSN 2455-2526; Vol.15, Issue 02 (May 2019)

Pg. no. 72-77.

Institute of Research Advances

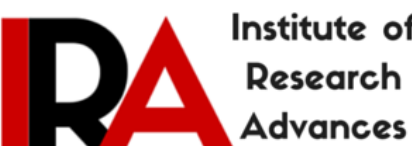

http://research-advances.org/index.php/IJEMS

\title{
Challenges Facing the Implementation of SMASSE'S ASEI/PDSI Approaches in Teaching
}

\author{
James Mwangi Kiige \\ P.O. Box 1358-00232 - Ruiru, Kenya.
}

Type of Work: Peer Reviewed

DOI: http://dx.doi.org/10.21013/jems.v15.n2.p3

\section{How to cite this paper:}

Kiige, J.M. (2019). Challenges Facing the Implementation of SMASSE'S ASEI/PDSI Approaches in Teaching. IRA International Journal of Education and Multidisciplinary Studies (ISSN 24552526), 15(2), 72-77.doi: http://dx.doi.org/10.21013/jems.v15.n2.p3

(C) Institute of Research Advances.

This work is licensed under a Creative Commons Attribution-Non Commercial 4.0 International License subject to a proper citation to the publication source of the work.

Disclaimer: The scholarly papers as reviewed and published by the Institute of Research Advances (IRA) are the views and opinions of their respective authors and are not the views or opinions of the IRA. The IRA disclaims of any harm or loss caused due to the published content to any party.

Institute of Research Advances is an institutional publisher member of Publishers International Linking Association Inc. (PILA-CrossRef), USA. The institute is an institutional signatory to the Budapest Open Access Initiative, Hungary advocating the open access of scientific and scholarly knowledge. The Institute is a registered content provider under Open Access Initiative Protocol for Metadata Harvesting (OAI-PMH).

The journal is indexed \& included in WorldCat Discovery Service (USA), CrossRef Metadata Search (USA), WorldCat (USA), OCLC (USA), Open J-Gate (India), EZB (Germany) Scilit (Switzerland), Airiti (China), Bielefeld Academic Search Engine (BASE) of Bielefeld University, Germany, PKP Index of Simon Fraser University, Canada. 


\begin{abstract}
Kenya, like most other developing countries, is beginning to address a wide range of problems with the heightened concern for the role played by In-service Education and Training (INSET) in improving the quality of education. Opportunities for learning through in-serving training continue to open up for teachers, a fact that has seen the initiation of programmes such as Strengthening Mathematics and Science in Secondary Education (SMASSE). SMASSE utilizes two approaches to teaching; Activity, Student-centred, Experiment, Improvisation (ASEI) and Plan, Do, See, Improve (PDSI). This paper is an instrumental guide into government decisions on the SMASSE project which has so far highlighted many challenges being faced both by the teachers and the students in the implementation process. This study proposes from the point of implementers and consumers, ways to counter the challenges. This implies that the areas of weaknesses can then be addressed. The study used a total of sixteen schools selected through stratified random sampling. The study gathered both qualitative and quantitative data which was analyzed using Statistical Package for Social Sciences (SPSS) software, Registered $R$ and Excel. Findings are presented in tables using percentages, frequency distribution and means. A number of challenges in the implementation of SMASSE were identified. These included inadequate time, de-motivated teachers and students' indiscipline among others. The study concludes that though SMASSE INSET does not show an impact on the performance of mathematics and chemistry, it has influenced the teachers' ability to deliver in their teaching amidst various challenges. The author thus recommends that future SMASSE programmes should have a bottom-up approach to enable full ownership by stakeholders.
\end{abstract}

Keywords: SMASSE, Challenges, Implementation, INSET, Mathematics, Chemistry, Teacher training.

\title{
Introduction
}

Teacher education is expensive and for the most part, has not been very effective. While it is agreeable that teachers need good professional preparation before engaging in classroom activities, it is not clear if the high cost of current investments in teacher preparation has yielded adequate results. Experimentation with different strategies and models, research, and policy deliberations until now have led to only modest, if any, improvements in teacher quality and motivation [1]. This suggests the need for bold and creative thinking about alternative approaches to teacher preparation, including more flexible models of pre-service preparation, a new balance between pre-service and in-service programs, and the development of strong ongoing professional support programs for serving teachers [1].

Mathematics and sciences have originally been viewed as being critical for the attainment of industrialization in Kenya by the year 2020 and now the country's vision of becoming a mid-level economy by 2030 [2]. This has been a challenge to most schools as they are ill-equipped and have a shortage of mathematics and science teachers. The result is a decline in performance in mathematics and science subjects as echoed by the Kenya National Examination Council [3]. This has, in turn, led to many students failing to achieve the qualifying mark to tertiary mathematics and science-based institutions.

The adequacy of mathematics and science teachers in addition to the effectiveness of their teaching is critical to the development of a nation. This is because teachers remain one of the most important human resources that a country has and an efficient human capital development depends partly on the quality and effectiveness of the teachers [4]. The quality and effectiveness of the teacher is among others a function of the talent and the training. According to toAlsubaie [5], the training of teachers is one of the most important aspects of curriculum development and implementation in any education system. The study emphasizes the involvement of teachers in the development process of the curriculum to enable effectiveness. The enhancement of teachers' professional development, comprising pre-service, in-service and school-based activities, should be part of a vision for curriculum change that heavily emphasizes the different processes that could lead to the improvement of classroom practices [6]. It is with this background that the attention is now drawn to what classroom practices, utilization of the available equipment, materials, approaches and methodologies that are employed in content delivery [1].

SMASSE project was a bilateral technical cooperation intervention between Japan, through the Japan International Cooperation Agency (JICA) and the Kenya Government through the Ministry of Education, Science and Technology [7]. Its implementation was initiated in the country in 1998 (Centre for Mathematics, Science and Technology Education in Africa [8]. (CEMASTEA, 2009)) with a mission to strengthen Mathematics and Science (physics, chemistry and biology). The project was also mandated to promote education through pre-service and 
INSET, research, exchange of information through seminars and conferences, joint activities and all other lawful means to pursue its objectives.

By the year 2008, the project had since been implemented in over a ten year period from 1998 to 2008. In the first phase of the project (June 1998 -June 2003), the activities were initiated on a pilot basis in nine districts with six additional districts (Baringo, Garissa, Kiambu, Kilifi, Meru South and Taita-Taveta)being brought on board in 2001. The second phase was implemented from July 2003-December 2008 on a national scale due to the success of the first phase [8]. CEMASTEA has continued to carry on with the implementation of the SMASSE programmes by extending to primary schools besides the originally intended secondary schools. Consequently, SMASSE was changed to Strengthening of Mathematics and Science Education (SMASE) so as to accommodate both the primary and secondary school activities. Its capacity building programmes are for both the secondary and primary schools and its implementation is spearheaded by Centre for Mathematics, Science and Technology Education in Africa (CEMASTEA) [8].

CEMASTEA was established in 2006 due to a large number of teachers involved in Phase II. Upon expiry of the project period for phase II the MOEST upgraded the project to programme status effective January 2009. This means that the Government of Kenya through the MOEST solely funds all the activities of the SMASSE programme.

SMASSE has also given a chance for the mathematics and science teachers to exchange ideas learnt from one another and provide for a system of monitoring and follow up. This is meant to ensure that the resolutions and decisions arrived at during the training sessions in addition to the ASEI and PDSI principles are implemented at the classroom level to improve the learning process. The use of this approach begun to bear fruits since the general improvement in learning has been observed [8].

Besides, there is ownership of the programme by the teachers. Feedback reports from County trainers, Quality Assurance and Standards Offices (QASO), County Education Officers (EOs) and principals have shown that SMASSE activities have improved classroom activities and accorded learners the opportunity to participate in lessons through hands-on activities [8]. In cases where conventional apparatus and equipment have been found to be inadequate, locally available materials have been used to teach concepts that would have otherwise been missed out. Teachers have also been reported to have developed a positive attitude towards work planning especially lesson planning and embraced teaching in the same school [8]. These observations, according to the reports have contributed to increased enrolment of students (both boys and girls) in science subjects in the Kenya Certificate of Secondary Education (KCSE) and increased admission to science-based courses at post-secondary institutions and universities. They have also enhanced students' participation in Congress on science and engineering fair at the subcounty and county levels. All these are attributed to the positive attitudes of both the students and the teachers towards mathematics and science.

Despite the successful implementation of SMASSE Phase I and II and the gains so far made, several gaps have been identified through continuous monitoring and evaluation activities. These have been reported in several reports which include Monitoring and Evaluation reports, SMASSE Project Impact Assessment Survey (SPIAS) report [9], and Statistical Analysis of SMASSE Project Impact Assessment Survey, Kenya [10] among others. One of the gaps identified is the quality of facilitation during the INSET which has been rated below the required standards. Moreover, every county is required to conduct INSET at the county level, with the support of CEMASTEA. This puts a great responsibility to the county trainers, who are also classroom teachers. However, with proper capacity development and support, the teachers are expected to be able to carry out their responsibility as teachers and trainers with ease.

\section{Materials and Methods}

The study was carried out in Secondary schools in Kikuyu District in Central Province currently represented by the Kikuyu Sub-county in Kiambu County in the new administrative structure. Kikuyu Sub-county is one of the recently formed sub-county having been curved from the greater Kiambu County. It is a highly populated peri-urban area approximately 20 kilometres west of Nairobi, the capital city of Kenya. The study used descriptive research design. A Research design defined as the plan and structure of investigation so conceived as to obtain answers to research questions [11]. Descriptive design, according to Jupp[12] and as used in this study seeks to establish the challenges 
of SMASSE training in dissemination, understanding of mathematics and chemistry and the actual performance in KCSE. According to Kombo and Tromp [13], the major purpose of descriptive research is a description of the state of affairs as it exists. Descriptive research can result in the formulation of an important solution to significant challenges and problems.

The study was focused on both public and private secondary schools that had sat for the KCSE since the introduction of SMASSE. The schools were sampled by stratified random sampling from the total number of national, extra-county schools, county and sub-county schools in terms of private and public secondary schools in the. Kikuyu Sub-county was selected as it is one of those that benefited with the initial SMASSE training. It was also one of the areas that have been performing poorly in KCSE in the central region. A sample size of sixty per cent of the secondary schools in Kikuyu was selected using the following formula:

$$
\frac{\text { Total number of schools in the strtaum }(N)}{\text { Total number of schools in the constituency }} \text { X60\% }=16 \text { schools }
$$

Two different types of questionnaires were used: for Principals and teachers. The Principals of the sampled schools filled in the questionnaire for the Principals while mathematics and chemistry teachers filled in the questionnaire for the teachers. One teacher in each subject (mathematics and chemistry) was sampled in each school. The instrument sought information regarding methodologies and challenges facing SMASSE implementation. Available documents from the Ministry of Education on KCSE analysis were also reviewed to determine the performance. Data analysis for the qualitative data was done by content analysis. Quantitative data was, on the other hand, analyzed using SPSS. Inferential statistics were used in making deductions and generalizations about the whole population. The inferential statistics were tested at $\alpha<0.05$ significance level. Data presentation was done using tables, graphs and narratives.

Regression was also used to compare the mean performance of students for 1999-2000 (before SMASSE INSET started) and 2004-2008 that comprises the years the teachers went through the four- cycle SMASSE INSET.

\section{Results and Discussion}

The study identified a number of challenges impeding successful implementation of SMASSE project. Time, lack of resources, and negative attitude of teachers were identified as significant barriers to implementation of ASEI/PDSI approaches as shown in Table 1. Some of these responses were echoed by the principals who noted lack of time, very wide syllabus, lack of equipment and negative learners' attitude as significant barriers. When asked for possible ways of dealing with the challenges, about two-thirds of the teachers did not answer. Among those who answered, half $(50 \%, \mathrm{n}=10)$ felt that there is a need for allocation of more time to allow coverage of the syllabus. About a third of the respondents felt that the way forward was for the Kenya National Examination Council to set easier questions for the students. The principals felt that motivating the teachers and the learners, condensing of the syllabus and ensuring that SMASSE programme is teacher driven and not the ministry of education driven were some possible ways of addressing the challenge.

Table 1: Barriers to the successful implementation of skills learnt in SMASSE INSET

\begin{tabular}{lll}
\hline Barriers to implementation of learnt skills & Frequency & Percentage (\%) \\
\hline Time & 13 & $\mathbf{4 1 . 9}$ \\
The negative attitude of teachers & 5 & $\mathbf{1 6 . 1}$ \\
Lack of resources & 6 & $\mathbf{1 9 . 4}$ \\
In disciplined students & 3 & $\mathbf{9 . 7}$ \\
Syllabus too wide & 2 & $\mathbf{6 . 5}$ \\
De-motivated students & 1 & $\mathbf{3 . 2}$ \\
De-motivated staff & $\mathbf{3 . 2}$ \\
\hline
\end{tabular}

When asked to identify challenges facing effective utilization of skills learnt in SMASSE INSET, a fifth (20.69\%, $\mathrm{n}=29$ ) did not respond. Those who responded cited lack of adequate time for lesson preparation, lack of resources and negative teachers' attitudes toward teaching as the main challenges to the successful implementation of skills learnt in SMASSE INSET. A number of teachers $(17.4 \% \mathrm{n}=23)$ were of the opinion that SMASSE should be taught in college other than as an INSET. 
Given the chance to comment on the SMASSE INSET, a fifth of the teachers $(20.6 \%, \mathrm{n}=29)$, declined to comment. Of those who commented, the majority felt that it should be organized in consultation with teachers. The others had different opinions as depicted in Table 2.

Table 2: Teachers comment on the SMASSE INSET

\begin{tabular}{lll}
\hline Respondents comments & $\begin{array}{l}\text { No of } \\
\text { respondents }\end{array}$ & Percentage \\
\hline SMASSE is useful & 4 & $\mathbf{1 7 . 4}$ \\
Give incentives to teachers to motivate them & 1 & 4.3 \\
Come up with new ideas on what to train, SMASSE has been here & 2 & $\mathbf{8 . 7}$ \\
for too long & & \\
SMASSE programme should be conducted once a year, not twice & 1 & $\mathbf{4 . 3}$ \\
SMASSE should be done in training colleges & 4 & $\mathbf{1 7 . 4}$ \\
It needs more time & 3 & $\mathbf{1 3 . 0}$ \\
Should cover the whole country & 3 & $\mathbf{1 3 . 0}$ \\
Should be organized in consultation with teachers & 5 & $\mathbf{2 1 . 7}$ \\
\hline Total respondents & $\mathbf{2 3}$ & $\mathbf{1 0 0}$ \\
\hline
\end{tabular}

Challenges to the successful implementation of what was learnt in SMASSE INSET revealed that there is still more work needed to change the teacher's attitude and if need be to revise the mathematics and chemistry syllabus. In future, students and teachers motivation and discipline of students should feature as this needs to be addressed. This was evident from the students who noted that both mathematics and chemistry are hard, time-consuming and have equations that are very confusing. This finding on the challenges to the successful implementation of what was learnt agrees with AED [1] statement that "teachers indicate that, although higher salaries would encourage better performance, improvements in conditions of service are also very important in promoting job satisfaction, motivating teachers, and promoting retention. Teachers express a strong desire for more professional support in general; better teaching and learning resources, supportive supervision, and ongoing in-service professional development".

In another study conducted by Waititu and Orado[14], some of the challenges identified were said to be beyond SMASSE's scope. They included interruption of the school programme as a result of students being sent home for school fees, transfer of teachers, demoralized teachers due to job stagnation, understaffing in some areas of curriculum development among others. However, Kibe, Odhiambo and Atengo [15] established that despite these challenges, some schools were still recording poor performance in Mathematics and Science subjects even with sufficient equipment and materials.

On the way forward there was a general feeling among the teachers that SMASSE should be organized in consultation with teachers while the students felt that the two subjects should be taught in the morning session by motivated teachers, and if this is not possible the two should be made optional.

\section{Conclusion}

There are a number of challenges affecting the successful implementation of the learning approaches to teaching. The challenges include inadequate time, negative attitude portrayed by the teachers, lack of required resources, indisciplined students among others. To address this, there is a need for consultative planning, implementation and evaluation of the SMASSE program. This should involve all the stakeholders including education managers, policy makers, teachers and students.

\section{Recommendations}

- Any future program by the ministry should use a bottom-up approach where the consumers are supported to identify the problem and look for ways of addressing it in consultative forums. This will create ownership of the program by all the stakeholders

- Science teachers workload should be reduced to give them adequate time to plan and prepare for the lessons 
- To enable teachers to deal with lack of resources principals should be encouraged to have a kitty in the budget to assist science teachers to look for locally available materials for improvisation purposes

- A counselling component in the secondary education system should be emphasized to improve students' discipline. This should involve all stakeholders including students, parents and teachers.

\section{References}

[1]. ADEA (2005). Mathematics and Science. Innovations in the Classroom. Assistance for the development of education in Africa.

[2]. Government of Kenya (GOK), (2008). Kenya Vision 2030: A Globally Competitive and Prosperous NationNairobi: Government Printers.

[3]. Kenya National Examination Council (KNEC), (2002). The year 2001 KCSE examination candidates' performance report. Nairobi: KNEC.

[4]. Okumbe, J.A. (1999). Education Management: theory and practice. Nairobi: University Press.

[5]. Alsubaie, M. A. (2016). Curriculum Development: Teacher Involvement in Curriculum Development. Journal of Education and Practice 7(9), 106-107.

[6]. UNESCO (2006). Role and Dimensions of Teacher Development No.3 IBE/UNESCO, Switzerland.

[7]. Ministry of Education Science and Technology (MOEST), (2000). Education for All (EFA) in Kenya. Nairobi: Government Press.

[8]. CEMASTEA (2009). Situational Analysis of SMASSE District INSETs. Nairobi: Pronto Typographer's Limited.

[9]. SMASSE Project Report (2007). Report on the survey of the impact of the SMASSE INSET in Kenya. Nairobi: SMASSE.

[10]. JICA (2009). Statistical Analysis of SMASSE Project Impact Assessment Survey (Kenya).

[11]. Cooper, R. D. \& Schindler, P. S. (2008). Business Research Methods, Tenth Edition. Singapore: McGraw Hill.

[12]. Jupp, V. (2009). The SAGE Dictionary of SOCIAL RESEARCH METHODS. London: Sage publications Ltd.

[13]. Kombo, D.K. \& Tromp, L.A. (2006). Proposal and Thesis Writing: An introduction. Nairobi: Pauline's Publications Africa

[14]. Waititu, M. \& Orado, G. (2009). Managing Teachers and instruction of mathematics and science: Lessons from SMASSE experience in capacity development. Paper presented at Secondary Education in Africa (SEIA) Follow up Technical Workshops on science and Mathematics in Tunisia.

[15]. Kibe S. Odhiambo J. \& Atengo O. (2008) Beyond Primary Education: Challenges and Approaches to expanding learning opportunities in Africa. Maputo. Association for the Development of Education in Africa. 